\title{
The Optimization of College Music Teaching based on Multimedia Technology
}

\author{
Bing Xia ${ }^{1, a}$ \\ ${ }^{1}$ Music School,Jiangxi Science \& Technology Normal University, Nanchang, China \\ axiab8899@163.com
}

\begin{abstract}
Keywords: multi-media teaching, college, music teaching
Abstract: The application of multimedia technology in college music teaching has important practical significance. The article analyzes the effect of multimedia technology in music teaching and discusses the optimization of multimedia technology in music teaching on the basis of the principles adhered to from the practice of music teaching.
\end{abstract}

\section{Introduction}

Teaching media is an important part of modern education technology. With continuous innovation and development of education philosophy and education technology, multimedia teaching has become one of the essential teaching activities means increasingly. Especially in ever-changing today, the application of multimedia can let the students understand the music, express the music and create the music better, to make the unreal music image concrete, the complex knowledge simple, disordered knowledge structured, which makes up for the shortcomings of classroom teaching and adds infinite charm to music teaching. Applying the computers, multimedia and other higher technologies in music teaching puts forwards new requirements to the teachers, and how to use the teaching media scientifically and reasonably is an important subject for music teachers worthy further research.

\section{The role of multimedia music in college music teaching}

Stimulate the students' learning interest. College students, with keen sense of music, have certain understanding of modern music and have their own interest area. However, traditional teaching methods can not make them learn what acquired in training and the music knowledge they desire to understand, so their learning interest is not strong. They like music, but they don't like the music course. In multimedia music, the modern music material, with the characteristics of simple and easy to operate, can inspire the students' strong desire to practice personally. Music is no longer to learn what teachers require, but what the students want to learn and hear. Music is no longer a burden, but a way to express them.

Enrich the music teaching method. The multimedia teaching means, with organic combination of image and text, is used in music teaching can inspire the students' emotion, arouse the students' subjectivity, and improve the teaching effect to a large extent. MIDI music, connecting with text, images, animation, video and other multimedia information, can naturally arouse the students' enthusiasm and initiative to enjoy the music. The students can take the initiative to feel the strength, speed, and mood of the music under the guidance of teachers. At the same time, while enjoying beautiful graphics and MIDI music, the students may produce kinds of vivid imagination as immersive general and inspire strong desire of music performance and creation.

Emphasize the personality development. Through the computer music production system, the notes can be put into the computer quickly and the actual sound effect of the music can be heard after one or two hours. Once hear the wrong or unsatisfied, you can modify immediately on the computer. In the process of modifying the work, students can hear what problems and shortcomings of their own work directly and how to modify and improve. The modernization teaching method makes the students' learning easier, more convenient, and more interesting. It not only facilitates their learning, but also satisfies their demand of analyzing different music work. Then the students can choose their own music 
work according to their own preferences, which open up the space for the development of the students' personality. The multimedia teaching is the development direction of music teaching.

\section{The application principles of multimedia technology in college music teaching}

The use of multimedia technology should adhere to the principle of pertinence. The production of multimedia courseware must have clear purpose. Whether it is the demonstration courseware helping to solve the difficulty or the interactive courseware reflecting students' autonomous learning, it must serve the teaching. If use multimedia tools in the music class, teachers should start from the careful preparation, determine the teaching contents and teaching objectives, clear teaching ideas, and design the teaching process. The insertion of the courseware in the classroom should be done well in advance and designed the best use program. Classroom teaching is an activity full of personality. According to the teaching contents and their own advantages, teachers can choose the multimedia production software and all kinds of audio and video materials needed in the music course. Good courseware can be produced on the basis of the optimization design of teaching under the guidance of modern education thought.

The use of multimedia technology should adhere to the principle of auxiliary. The music classroom teaching assisted by multimedia overcomes many deficiencies. It enables students to gain a lot of knowledge and information from multi channels and have higher retention rate of memory, effectively stimulates students' learning enthusiasm and motivation, promotes students' ability of perception, thinking and memory, and comprehensively improves the music teaching efficiency and process. However, in the real life, such a phenomenon exists: in order to better deal with teaching, music teachers may move all the materials collected into computer courseware, from flash to premiere and 3DMAX, etc. Therefore, the corresponding drawbacks forms: the teachers are busy with the operation while the students pay attention to the appreciation of the screen and ignore the interaction, communication, and exploration. We always advocate all for students and people-oriented. So, in the music multimedia courseware making and teaching, we should base on the feelings of students and the teaching effect, and follow the auxiliary principle of music multimedia courseware, so as to better make them master the knowledge and skills in a relaxed and happy atmosphere.

The use of multimedia technology should adhere to the principle of timely and appropriate. Compared with the traditional teaching media, using multimedia technology in teaching is more vivid and attractive due to mobilizing a variety of audio-visual means. Therefore, the use of multimedia technology should adhere to the principle of timely and appropriate. The timely principle: the use of multimedia should choose the teaching key point that the students can be easy to grasp and the time that the teaching can achieve the best effect. The appropriate principle: the use of multimedia should be just perfect, not far fetched. Not all the teaching contents and teaching links need to play a role through the multimedia, so the classroom should not become a multimedia presentation. Even the relevant contents, designed to solve the difficulty and promote the automotive learning, also should not pursue the richness unilaterally to avoid negative interference. It requires that the process of courseware design should focus on practical teaching effectiveness. The use of multimedia courseware is to serve the teaching, so it is necessary to pay attention $t$ the harmony of the courseware production to play the best effect. In the process of music teaching, using the multimedia technology needs to identify the starting point of the multimedia and teaching content.

\section{Ways of optimizing the music teaching through modern multimedia technology}

Strengthen the training of the music teachers' multimedia technology ability. Using multimedia technology in music class requires that the music teachers should not only have the ability of traditional teaching, but also have the ability of modern multimedia technology. It contains: the first, master the computer basic knowledge. The computer is the most critical equipment in the music teaching and is the control center of the multimedia external equipments in the music teaching. And the computer software, such as word processing software, courseware production software, etc, is what the music 
teachers must master. PowerPoint, the concentrated expression of the multimedia technology, can mix the video, audio, animation and other multimedia materials for editing and making courseware. Therefore, it is necessary for the teachers to master the computer technology. The second, master the computer music editing software. There are many kinds of software for editing and making music. It can be divided into three categories: music composition software, music production software, and music editing software. Teachers can choose to learn and master the software according to their own profession and teaching courses.

Build the electronic MIDI music studio and the electric piano classroom. At present, the university multimedia classroom is usually equipped with computer, projector, and sound box and so on. These devices provide a lot of convenience for the general teaching work, but there are still a lot of problems for the music profession. MIDI equipment can provide high quality audio effect, free control audio and standard console modified at any time, which are needed in music teaching. In addition, MIDI system has good compatibility, so the sound card can be connected with other musical instruments through the MIDI data cable, equivalent to a huge band. In the professional music composition, orchestration, harmony and other courses requiring higher sound quality, the MIDI devices can create the best music environment for the students, capture musical inspiration timely, and then choose the appropriate music motivation and development variation of musical theme. With the increasing college music professional students, the teaching task of piano teacher is increasing, and the traditional teaching method can not satisfy the real demand. Therefore, it is very urgent to build a multimedia electric piano classroom. It breaks the traditional piano teaching model, makes the unison and ensemble teaching methods easier to achieve, and also provide convenient conditions for students to learn from each other.

Strengthen the construction of modern information database. In music teaching, college teachers should use the resources rationally to carry out teaching activities flexibly, so as to provide the necessary conditions for lesson preparation and students' learning. Firstly, improve the teacher's training system. Organize the teacher training by the repository technology teachers to improve teachers' knowledge and technical ability. Secondly, develop the resources of music education and teaching information and establish a rich and perfect music education information resource library to let every teacher learn others' teaching experience timely and grasp education information to improve their work ability. Thirdly, strengthen the internal and external cooperation, and achieve the sharing of education and teaching information through computer network technology, so as to better promote the modernization process of music education.

\section{Summary}

With the rapid development of information technology, the country pays great attention to education and increases investment in education funding continuously. In the big background, college music education should seize the opportunity and make full use of multimedia technology in music teaching, so as to inspire students' learning interest, mobilize their learning enthusiasm, increase their learning opportunities, let them learn in relaxed and pleasant atmosphere, and improve the music teaching level and quality comprehensively.

\section{References}

[1]Wenli Gong. The application of multimedia in college music teaching[J]. The Chinese Adult Education, 2009,(8): 145-146.

[2]Qian Liang. The application of multimedia in music appreciation[J]. Jounrnal of Xinjiang Vocational University, 2009,17(1).

[3]Lifang Cao. Exploration and practice of multimedia teaching in college basic piano[J]. Journal of Hunan science and technology university, 2008, 29(1) 
[4]Chenggui Song. The application of modern educational technology in solfeggio teaching[J]. The education of Jilin, 2010,(3):66-67.

[5]Ping Xie. Some thought on the innovation of music education in ordinary colleges[J]. Journal of Changsha Unversity( social science edition), 2012(5).

[6]Qiyun Chen. The theory and application of computer music[M]. 2005.

[7]Yingzhou Xu. The application of multimedia technology in college music teaching[J]. Journal of Jilin Engineering Technology Normal Unversity, 2010,(11). 